\title{
Penerapan Model Pair Checks Untuk Meningkatkan Prestasi Belajar IPS Kelas VI
}

\author{
Siti Zaenab
}

\author{
SDN 1 Pogalan Kecamatan Pogalan Kabuapten Trenggalek \\ Email: sitizaenab656@yahoo.co.id
}

\section{Tersedia Online di \\ http://www.jurnal.unublitar.ac.id/ index.php/briliant}

\begin{tabular}{l}
\hline Sejarah Artikel \\
\hline Diterima pada 25 Juli 2017 \\
Disetuji pada 25 Juli 2017 \\
Dipublikasikan pada: 2 Agustus \\
2017 Hal 402-406 \\
\hline
\end{tabular}

Kata Kunci:

pair checks, prestasi belajar, ips

\begin{abstract}
Abstrak: Mata pelajaran Ilmu Pengetahuan Sosial (IPS) seringkali dianggap sulit sehingga banyak siswa yang gagal atau mencapai nilai (prestasi belajar) yang relatif rendah. Untuk itu perlu dilakukan tidakan guna mengatasi permasalahan tersebut. salah satu tindakan yang tepat adaah dengan menerapkan model pembelajaran pair cheks. Sehingga tujuan penelitian ini untuk mengetahui peningkatan prestasi belajar mata pelajaran Ilmu Pengetahuan Sosial (IPS) materi gejala alam dengan model pembelajaran Pair Checks (pasangan mengecek). Hasil penelitian menunjukkan adanya eningkatan prestasi beajar IPS setelah menggunakan model ini. Anak yang memenuhi KKM telah melebihi angka ketuntasan kelas.
\end{abstract}

Mata pelajaran Ilmu Pengetahuan Sosial (IPS) seringkali dianggap sulit sehingga banyak siswa yang gagal atau mencapai nilai yang relatif rendah. Kesulitan mata pelajaran Ilmu Pengetahuan Sosial (IPS) dapat disebabkan oleh berbagai faktor misalnya materi yang cukup luas dan selalu berkembang, faktor guru dengan segala aspeknya, atau cara belajar siswa yang kurang tepat. Maka dari itu diperlukan suatu tindakan nayata untuk meningkatkan prestasi belajar siswa tersebut. Khususnya pada siswa kelas IV.

Prestasi belajara merupakan gabuangan dari prestasi dan belajar. Prestasi adalah hasil baik yang dicapai (Fajri, 2008). Sedangkan belajar adalah suatu proses perubahan di dalam diri manusia. Apabila setelah belajar tidak terjadi perubahan dalam diri manusia, maka tidaklah dapat dikatakan bahwa padanya telah berlangsung proses belajar (Aqib, 2012:43). Belajar adalah suatu bentuk pertumbuhan atau perubahan dalam diri seseorang yang dinyatakan dalam caracara bertingkah laku yang baru berkat pengalaman dan latihan. Tingkah laku yang baru itu misalnya dari tidak tahu menjadi tahu, timbulnya pengertian baru, serta timbul dan berkembangnya sifat-sifat sosial, susila, dan emosional. (Aqib, 2012:42). Memahami kutipan di atas, maka prestasi belajar merupakan usaha maksimal siswa dalam belajar

Ada beberapa prinsip belajar yang harus dipahami oleh individu yang sedang melaksanakan kegiatan belajar, sehingga kegiatan belajar yang dilaksanakan dapat mencapai keberhasilan yang maksimal. Adapun prinsip belajar yang dimaksud adalah motivasi, perhatian dan pemusatan energi psikis terhadap pelajaran erat kaitannya dengan motivasi, aktifitas belajar itu sendiri adalah aktifitas, umpan balik di dalam belajar sangat penting, supaya siswa segera mengetahui benar tidaknya pekerjaan yang ia lakukan, perbedaan individual 
adalah individu tersendiri yang memiliki perbedaan dari yang lain (Djamarah, 2012:28).

Guna mecapai prestasi belajar tersebut, maka tindkan yang tepat adalah dengan menerapkan mdel pair checks. Model pembelajaran pair checks (pasangan mengecek) merupakan model pembelajaran di mana siswa saling berpasangan dan menyelesaikan persoalan yang diberikan Dalam model pembelajaran kooperatif tipe pair checks guru bertindak sebagai motivator dan fasilitator terhadap aktifitas belajar siswa. Model pembelajaran ini juga melatih rasa sosial siswa, kerjasama dan kemampuan memberikan penilaian. Model ini bertujuan untuk meningkatkan kemampuan siswa dalam menuangkan ide, pikiran, pengalaman, dan pendapatnya dengan benar. Dengan strategi pair checks memungkinkan siswa untuk saling bertukar pendapat dan saling memberikan saran (Shoimin, 2014:89).

Langkah-langkah dari model pembelajaran pair checks, membagi siswa ke dalam kelompok yang terdiri dari 4 orang menjadi berpasang-pasangan (partner A dan partner B); berikan setiap pasangan LKS untuk dikerjakan (genap), berikan kesempatan kepada partner A untuk mengerjakan soal no 1 dan partner B mengamati, memberi motivasi, membimbing selama mengerjakan soal no. 1; selanjutnya bertukar peran, partner B mengerjakan soal no. 2 dan partner A mengamati, memberi motivasi, membimbing selama mengerjakan soal no 2; setelah 2 soal diselesaikan, pasangan tersebut mengecek hasil pekerjaan mereka berdua dengan pasangan lain yang satu kelompok dengan mereka. Guru memberikan pembimbingan bila kedua pasangan dalam kelompok tidak menemukan kesepakatan.

Melihat keunggulan dan langkah dari model ini, sangat penting dilakukan penelitian guna membuktikan keunggalannya. Kemudian dilakukan penelitian dengan tujuan untuk mengetahui peningkatan prestasi belajar mata pelajaran Ilmu Pengetahuan Sosial (IPS) materi gejala alam dengan model pembelajaran Pair Checks (pasangan mengecek).

\section{METODE}

Penelitian ini merupakan penelitian tindakan kelas (PTK) yang terdiri dari empat tahap yang dilaksanakan pada masing-masing siklus yaitu perencanaan (planning), pelaksanaan (acting), pengamatan (observating), dan refleksi (reflecting). Subjek penelitian ini adalah seluruh siswa kelas VI SDN 1 Pogalan Semester II tahun pelajaran 2015/2016 sebanyak 28 siswa (16 laki-laki dan 12).

Data pada penelitian ini diperoleh dengan metode observasi dan metode tes. Observasi aktifitas siswa digunakan untuk mengamati keterlibatan siswa secara aktif selama pembelajaran. Lembar observasi/pengamatan dipergunakan untuk mencatat jumlah siswa aktif dan siswa tidak aktif. Sedangkan lembar soal test akhir dipergunakan untuk mengetahui daya serap siswa. Lembar soal test akhir terdiri dari 10 soal pilihan ganda. Masing-masing soal dijawab benar memperoleh skor 10. Dengan demikian apabila siswa mampu menjawab 10 soal dengan benar, nilai maksimalnya adalah 100 .

Data-data yang diperoleh dengan mempergunakan metode pengumpulan data di atas, selanjutnya akan dianalisis. Tanpa dianalisis maka data tidak dapat memberikan arti dalam suatu penelitian. Data dianalisis dengan menggunakan metode analisis data statistik. 
Analisis data dilakukan dengan data hasil pengamatan keaktifan siswa yang dianalisis dengan cara mencari prosentase keaktifan dan ketidakaktifan siswa.

Siswa aktif $\quad=\frac{\text { Jumlah siswa yang aktif }}{\text { Jumlah siswa seluruhnya }(28)}$

Data prestasi belajar siswa dianalisis dengan cara Siswa dianggap tuntas apabila mampu memperoleh nilai minimal 70 (KKM pada materi ini adalah 70), dan mencari nilai rata-rata kelas.

$$
\text { Rata-Rata }=\frac{\text { Jumlah skor seluruhnya }}{\text { Jumlah siswa (28) }}
$$

Mencari prosentase ketuntasan dengan cara:

$$
\text { Ketuntasan }=\frac{\text { Jumlah Siswa Tuntas }}{\text { Jumlah siswa seluruhnya (28) }}
$$

Siswa dikatakan tuntas belajar secara individu jika siswa tersebut memperoleh skor hasil tes minimal 70, sedangkan ketuntasan belajar siswa secara klasikal paling sedikit $80 \%$ siswa tersebut tuntas belajar secara individu.

\section{HASIL}

\section{Pra Siklus}

Materi yang dikaji pada tahap pra siklus adalah ekspor dan impor barang dan jasa dengan indicator mengidentifikasi gejala alam yang menguntungkan dan merugikan dengan metode ceramah dalam proses pembelajaran di kelas. Datadata yang ditampilkan dari proses pendataan yang dilakukan melalui kajian adalah diketahui bahwa siswa tuntas sebanyak 10 siswa atau sebesar36\%, siswa yang tidak tuntas dalam belajar sebesar 18 siswa atau 64\%. Modus pada tahap pra siklus berada pada nilai $<70$ atau berada pada kualifikasi kurang yakni sebanyak 18 siswa (64\%). Pengamatan yang dilakukan oleh guru memperoleh hasil 13 siswa (46\%) aktif dan 15 siswa (54\%) tidak aktif. Dari proses kajian pra siklus tersebut maka peneliti perlu melakukan kajian dan tindakan pembelajaran dengan metode terpilih dalam pembelajaran lanjut, yakni dengan menggunakan metode Pair Checks (Pasangan Mengecek).

\section{Siklus I}

Pertemuan 1, tahap perencanaan dan pelaksanaan tindakan dilakukan dan dipersiapkan dengan mendesain pembelajaran sesuai dengan model pembelajaran Pair Checks (Pasangan Mengecek). Tahap pengamatan pada siklus I pertemuan 1 ini selama pembelajaran berlangsung, hasil pengamatan menunjukkan 14 siswa (50\%) siswa aktif dan sebanyak 14 siswa (50\%) tidak aktif.

Pertemuan 2 siklus I, tahap perencanaan dan tahap-tahap pelaksanaan tindakan dilakukan dan dipersiapkan sesuai desain pembelajaran model pembelajaran Pair Checks (Pasangan Mengecek). Pengamatan untuk tahap siklus I pertemuan kedua ini selama pembelajaran berlangsung hasil menunjukkan sebanyak 18 siswa (64\%) siswa aktif dan sedangkan sebanyak 10 siswa (36\%) tidak aktif.

404 BRILIANT: Jurnal Riset dan Konseptual Volume 2 Nomor 3, Agustus 2017 


\section{Refleksi Siklus I}

Berdasarkan data-data yang dikaji, maka dapat diketahui bahwa siswa tuntas sebanyak 21 siswa atau sebesar $75 \%$. Siswa yang tidak tuntas dalam belajar sebesar 7 siswa atau 25\%. Nilai rata-rata kelas yang dapat dicapai adalah 77. Dilihat dari kualifikasinya, sebanyak 3 siswa (11\%) berada dalam kualifikasi sangat memuaskan. Sebanyak 4 siswa (14\%) berada dalam kualifikasi memuaskan. Sebanyak 9 siswa (32\%) berada dalam kualifikasi lebih dari cukup. Sebanyak 5 siswa (18\%) berada dalam kualifikasi cukup dan sebanyak 7 siswa (25\%) berada dalam kualifikasi kurang. Modus pada tahap siklus I berada pada nilai 80 atau berada pada kualifikasi lebih dari cukup, sebanyak 9 siswa (32\%).

Berkaitan dengan data dan simpulan pelaksanaan tahap siklus I, dapat dianalisis/dikaji bahwa siswa lebih aktif dalam pembelajaran, walupun masih terlihat malu dan ragu-ragu, pada saat pembelajaran berlangsung guru lebih banyak duduk di kursi guru dan kurang memotivasi siswa. Berdasarkan simpulan atas kajian yang dilakukan, maka penelitian dilanjutkan pada siklus II.

\section{Siklus II}

Tahap perencanaan siklus II dilakukan dan dipersiapkan dengan mendesain pembelajaran sesuai dengan model pembelajaran Pair Checks (pasangan mengecek) sesuai dengann refleksi pada tahap sebelumnya. Pada pertemuan 1, tahap perencanaan dan tahap-tahap pelaksanaan tindakan sesuai dengan model pembelajaran tersebut. Pengamatan selama proses pembelajaran dilakukan, hasil pengamatan pada siklus II menunjukkan sebanyak 19 siswa (68\%) siswa aktif dan sebanyak 9 siswa (32\%) tidak aktif. Pertemuan 2 siklus II tahap perencanaan dan tahap-tahap pelaksanaan tindakan sesuai dengan model pembelajaran pair checks (pasangan mengecek). Pengamatan pertemuan kedua tahap siklus II ini hasil pengamatan menunjukkan sebanyak 22 siswa (79\%) siswa aktif, sedangkan sebanyak 6 siswa (21\%) tidak aktif.

\section{Refleksi}

Berdasarkan data-data yang dikaji dan ditemukan, maka dapat diketahui bahwa siswa tuntas sebanyak 25 siswa atau sebesar $89 \%$. Siswa yang tidak tuntas dalam belajar sebesar 3 siswa atau $11 \%$ dengan nilai rata-rata kelas yang dapat dicapai adalah 83. Dilihat dari kualifikasinya, sebanyak 6 siswa $(21 \%)$ berada dalam kualifikasi sangat memuaskan. Sebanyak 6 siswa $(21 \%)$ berada dalam kualifikasi memuaskan, sebanyak 9 siswa (32\%) berada dalam kualifikasi lebih dari cukup dan sebanyak 4 siswa (14\%) berada dalam kualifikasi cukup dan sebanyak 3 siswa (11\%) berada dalam kualifikasi kurang. Modus pada tahap siklus II berada pada nilai 80 atau berada pada kualifikasi lebih dari cukup, sebanyak 9 siswa (32\%). Berdasarkan hasil kajian yang dilakukan maka pelaksanaan tahap siklus II, dapat diambil kajian bahwa siswa sudah dapat menerapkan model pembelajaran pair checks (pasangan mengecek) dengan baik dan lancar, dan prestasi belajar siswa sudah meningkat dengan signifikan.

\section{PEMBAHASAN}

Perbandingan hasil belajar siswa pada siklus I dan siklus II, perbandingan ketuntasan belajar siswa dari siklus I dan siklus II dapat dianalisis bahwa siswa 
tuntas pada siklus I mencapai 21 siswa (75\%), sedangkan pada siklus II mencapai 25 siswa (89\%). Dengan demikian ada kenaikan tingkat ketuntasan belajar sebesar $14 \%$ atau sebanyak 4 siswa dari 28 siswa. Nilai rata-rata kelas yang dicapai siswa pada siklus I sebesar 77. Sedangkan pada siklus II naik menjadi 83. Dengan demikian nilai rata-rata kelas naik sebesar 6 poin. Siswa aktif pada siklus I sebanyak 18 siswa (64\%) sedangkan pada siklus II sebanyak 22 siswa (79\%). Dengan demikian ada kenaikan sebanyak 4 siswa (14\%).

\section{KESIMPULAN}

Berdasarkan hasil penelitian dan pembahasan yang telah diuraikan dapat diambil kesimpulan telah terjadi peningkatan prestasi belajar mata pelajaran Ilmu Pengetahuan Sosial (IPS) setelah menerapkan model pembelajaran pair checks (pasangan mengecek) bagi siswa kelas VI semester II tahun pelajaran 2015/2016 di SDN 1 Pogalan Kecamatan Pogalan Kabupaten Trenggalek. Hal tersebut berdasarkan analisis/kajian bahwa siswa tuntas pada siklus I mencapai 21 siswa (75\%), sedangkan pada siklus II mencapai 25 siswa (89\%), terjadi kenaikan tingkat ketuntasan belajar sebesar $14 \%$ atau sebanyak 4 siswa dari 28 siswa; nilai rata-rata kelas yang dicapai siswa pada siklus I sebesar 77. Sedangkan pada siklus II naik menjadi 83. Dengan demikian nilai rata-rata kelas naik sebesar 6 poin, dan siswa aktif pada siklus I sebanyak 18 siswa (64\%) sedangkan pada siklus II sebanyak 22 siswa (79\%), dengan demikian ada kenaikan sebanyak 4 siswa (14\%). Dengan demikian dapat dikatakan penerapan model pair checks dapat meningkatkan prestasi belajar ips untuk siswa kelas VI SD.

\section{SARAN}

Siswa hendaknya mempunyai motivasi belajar yang tinggi, berusaha sedapat mungkin untuk menghindari kebosanan pada saat belajar, selalu memandang positif terhadap berbagai macam metode dan model belajar yang dipergunakan, serta berupaya untuk menguasai berbagai macam metode yang diterapkan oleh guru. Guru hendaknya tidak merasa malas untuk menguasai berbagai macam metode, sehigga dapat memberikan motivasi tersendiri dalam proses belajar. Kepala Sekolah hendaknya selalu memberikan motivasi kepada semua guru/staf pengajar untuk selalu mengadakan inovasi dalam pembelajaran.

\section{DAFTAR RUJUKAN}

Aqib, Zainal. 2012. Profesionalisme Guru dalam Pembelajaran. Surabaya: Insan Cendekia

Djamarah, Syaiful Bahri.2012. Prestasi Belajar: Jakarta: Rineka Cipta

Fajar, Arnie. 2009. Portofolio. Bandung: Remaja Rosdakarya.

Fajri, Em Zul. 2008. Kamus Lengkap Bahasa Indonesia. Diffa Publishe.

S. Lusi., \& Samuel. 2013. Asyiknya Penelitian Ilmiah dan Penelitian Tindakan Kelas. Yogyakarta: CV Andi Offset

Shoimin, Aris. 2014. 68 Model Pembelajaran Inovatif dalam Kurikulum 2013.Yogyakarta:Ar-Ruzz Media. 